\title{
Beyond the use of an Explanatory Key Accompanying Submicroscopic Representations
}

\author{
Vesna Ferk Savec, * Špela Hrast, Iztok Devetak and Gregor Torkar \\ Faculty of Education, University of Ljubljana, Kardeljeva ploščad 16, 1000 Ljubljana, Slovenia \\ * Corresponding author: E-mail: vesna.ferk@ pef.uni-lj.si
}

Received: 23-08-2016

\begin{abstract}
When learning chemistry, students encounter various visualizations introducing scientific concepts and processes unobservable to the naked eye. It is often assumed that these visualizations support students' understanding and enable them to solve problems more efficiently. The research presented here investigates students' use of an explanatory key while solving tasks based on submicroscopic representations. The following features of the explanatory key were examined: 1) colored versus black-and-white, and 2) pictorial versus textual. Eye-fixation patterns and students' verbal explanations indicated that the presence of color in the key does not influence students' task solving. However, significant differences were observed with regard to a textual versus pictorial key used in the tasks: students spent more time and fixated more frequently on the key while solving tasks using a textual key in comparison to a pictorial key. The results indicate that the type of explanatory key might play an important role in revealing students' representational competence with regard to submicroscopic representations.
\end{abstract}

Keywords: Representational competence; submicroscopic representations; learning chemistry; explanatory key; eye tracking

\section{Introduction}

Learning about science, technology, engineering, and math (STEM) requires considering concepts and processes that are often invisible to the naked eye. Understanding such processes involves envisioning the components inherent in the events and the effects that emerge from their interactions. Failure to understand these processes and effects can result in wrong questions being posed, misconceptions, and poor course grades. ${ }^{1,2}$ Students' misunderstandings commonly occur with content that is based on understanding processes at a particulate level, such as the structure of matter and physical changes, ${ }^{3,4}$ solutions,${ }^{5-7}$ chemical reactions, ${ }^{8}$ equilibrium in aqueous solutions of electrolytes, ${ }^{9}$ and so on.

A variety of external representations are available to support students' understanding of abstract scientific processes. ${ }^{10,11}$ Researchers, starting with Johnstone, ${ }^{10,11}$ have proposed that the presentation of scientific concepts and processes be based on multiple representations, or a threefold manner of representing science, which includes a macroscopic level (observable phenomena), submicroscopic or particulate level (various representations of atomic, molecular, and particle structure), and symbolic level (mathematical and chemical symbols). Moreover, the interpretation of phenomena perceived at a macroscopic level by using submicroscopic representations is considered one of the fundamental ideas of modern chemistry and chemistry instruction. ${ }^{14}$ Such visualizations support students when connecting the three levels of concept representations, ${ }^{15,16}$ and they have been recognized as important tools in learning chemistry. ${ }^{17-20}$

However, in spite of the clear educational potential of visualizations, visual literacy is an often overlooked aspect of science education. ${ }^{21,22}$ Griffard $^{23}$ emphasized the importance of including visual literacy in undergraduate science classes because students must learn to recognize and understand the elements that compose complex representations. Tversky et al. ${ }^{24}$ emphasized that both diagrams and mental representations schematize, typically in the same ways. This implies that understanding peoples' mental representations of a domain is key to creating effective diagrams for the domain studied because the mental models suggest which information to include and which to omit.

Researchers ${ }^{25-27}$ have found that the use of visualizations also improves students' representational compe- 
tence. Stieff et al. ${ }^{27}$ interpret representational competence as a primary contributor to student learning in STEM because it comprises a distinct set of skills for constructing, selecting, interpreting, and using disciplinary representations for communicating, learning, or problem solving. According to research evidence, ${ }^{28-31}$ students' successful learning is significantly impacted by representational competence in chemistry. Kozma and Russell ${ }^{29}$ emphasized that representational competence in chemistry is crucial for learning chemistry because, in order to achieve expertise in the subject, students must master a specific set of skills related to representational competence. These include the ability to analyze features of a representation, transform one representation into another, generate different representations, clarify the usefulness of a given representation, and explain the distinctive affordances of different representations.

Rapp and Kurby ${ }^{32}$ believe that representational competence is important because visualizations are not automatically converted into knowledge and learners may have difficulties, for example, in recognizing features of a representation and its application in problem solving within a domain. For considering the implementation of representation in various kinds of teaching materials and classroom activities, it is therefore important to understand how to support students in their recognition of representational features. Semiotics is the study of the meaning of various signs that are used to communicate information through representation, and signs or symbols are thereby images, gestures, sounds, text, models, textures, and so on. ${ }^{33}$ Dreyfus ${ }^{34}$ organized symbols by graphic form into fourteen categories, such as blubs, circles, lines, arrows, squares, crosses, and so on. In process diagrams, arrows represent molecular processes, such as sequences, gradients, pathways, movement, increases, and decreases. ${ }^{35}$ Cutaways, zooming frames, and shading convey depth, scale, and three dimensions. ${ }^{36}$ In presenting submicroscopic representations, authors usually use a color convention to distinguish the atomic models presented for various chemical elements. The use of color convention varies by author, but most commonly they use the CPK coloring scheme, which was named after the designed in 1952 by the chemists and, and improved by Walter Koltun. ${ }^{37}$ Especially for novices, science education can be confusing when it is anticipated that they will be able to distinguish between different atoms, usually without an explanatory key enclosed with the submicroscopic representation. Some textbooks, ${ }^{38,39}$ on the other hand, have adopted specific color conventions for particle representations in their learning materials and also provide an explanatory key.

In order to avoid confusion by learners, it would be beneficial to accompany each of the submicroscopic representation in learning materials with an explanatory key, similarly as with geographical maps, where it is a generally recognized rule to embed an explanatory key (le- gend) into a representation, which then allows the reader to accurately recognize the map features.

Eye tracker is a promising instrument for studying various components of representational competence ${ }^{25,40,41}$ because it makes it possible to monitor cognitive processes as a consequence of the links between eye movements and cognition. ${ }^{42,43}$ With regard to this fact, collecting eye movements could also provide important information in investigating the role of an explanatory key in students' processing of submicroscopic representations in chemistry tasks derived from international and national assessment studies.

The main aim of this study was to investigate the role of a key in processing submicroscopic representations by students while solving specific chemical tasks. With regard to this research aim, the following research questions were defined:

- How does a colored versus black-and-white pictorial explanatory key affect students' way of solving chemistry tasks based on submicroscopic representations?

- How does a pictorial black-and-white versus textual explanatory key affect students' way of solving chemistry tasks based on submicroscopic representations?

\section{Methods}

\section{1. Participants}

For this investigation, 44 students were selected from the pool of 118 non-chemistry freshmen at the University of Ljubljana's Faculty of Education based on their achievements on a chemistry knowledge test. Four participants were excluded due to their absence at the eye-tracking session and five participants due to poor eye calibration. The final sample consisted of 35 participants with high total scores on the chemistry knowledge test (the top third of students with the highest scores).

\section{2. Materials and Apparatus}

\section{2. 1. Chemistry Knowledge Test}

Altogether, 118 students completed the paper-andpencil pretest $(\alpha=0.62)$ with 30 multiple-choice chemistry questions (each question worth one point) based on submicroscopic representations $(M=12.38 ; S D=4.52)$. This pretest served as the basis for recruiting high-priorknowledge participants with average scores higher than 16.71 points, $S D=2.86$ ). These students were included in the eye-tracking subsample in the second part of the study.

\section{2. 2. Eye Tracker}

For monitoring students' eye movements when solving submicroscopic chemistry tasks, we used the screenbased Tobii Pro X2-30 eye tracker. Gaze data were captu- 
red at $30 \mathrm{~Hz}$ with an accuracy of 0.4 degrees of visual angle at distances ranging between 40 and $90 \mathrm{~cm}$.

\section{2. 3. Problem Set}

The problem set consists of eight tasks based on submicroscopic representations derived from assessments such as TIMSS, PISA, and the Slovenian national chemistry assessment test (NPZ), but modified for the purpose of this study.

For investigating the role of the colored versus black-and-white explanatory key accompanying submicroscopic representations (Section 1), two different types of tasks were selected and modified. The first type (consisting of two tasks) required participants to solve tasks with submicroscopic representation including specific functional groups of organic compounds (carboxylic acid and alcohol), and the second type (consisting of two tasks) required solving tasks with submicroscopic representation with a chemical equation for simple chemical reactions. Each of the two tasks from each type involved different particle representations with an appropriate explanatory key: colored or black-and-white.

To examine the importance of pictorial versus textual presentation (Section 2) of the key explaining particles' nature, one type of task in which students had to de- termine which of the pictures represents simple commonly used compounds was selected and modified. Two tasks of this type contained a textual presentation and the other two tasks contained a pictorial presentation of the particle explanatory key.

All of the tasks from the same section are comparable with regard to complexity and type of visual representation. Comparable difficulty within the same section of tasks can also be seen from the participants' mean achievements (Table 1).

Tasks were displayed on the computer screen, one at the time. The time allowed for solving the task was not limited and the tasks were presented in random order.

\section{3. Eye-movement Measures}

To determine students' visual attention towards different elements of the tasks they were solving, we focused on the total amount of time (total fixation duration, TFD; in some studies also referred to as dwell time) and number of fixations (fixation count, FC) spent in particular areas of interest (AOI). For this purpose, the tasks displayed on the computer screen were divided into several AOIs with regard to the placement of particles investigated, text, the explanatory key, or the whole area of particles presented (see Figure 1). A fixation was determined as a process

Table 1. Students' mean achievements

\begin{tabular}{lccc}
\hline No. & Type of key & Content & Response accuracy (\%) \\
\hline 1 & \multirow{2}{*}{ Colored } & Functional groups of organic compounds & 64.71 \\
2 & & Writing the chemical equation & 79.41 \\
\hline 3 & \multirow{2}{*}{ Black-and-white } & Functional groups of organic compounds & 61.76 \\
4 & \multirow{2}{*}{ Textual } & Writing the chemical equation & 76.47 \\
\hline 5 & \multirow{2}{*}{ Simple common compounds } & 100.00 \\
6 & \multirow{2}{*}{ Pictorial } & & 97.01 \\
\hline 7 & & & 94.61 \\
8 & & & 87.45 \\
\hline
\end{tabular}

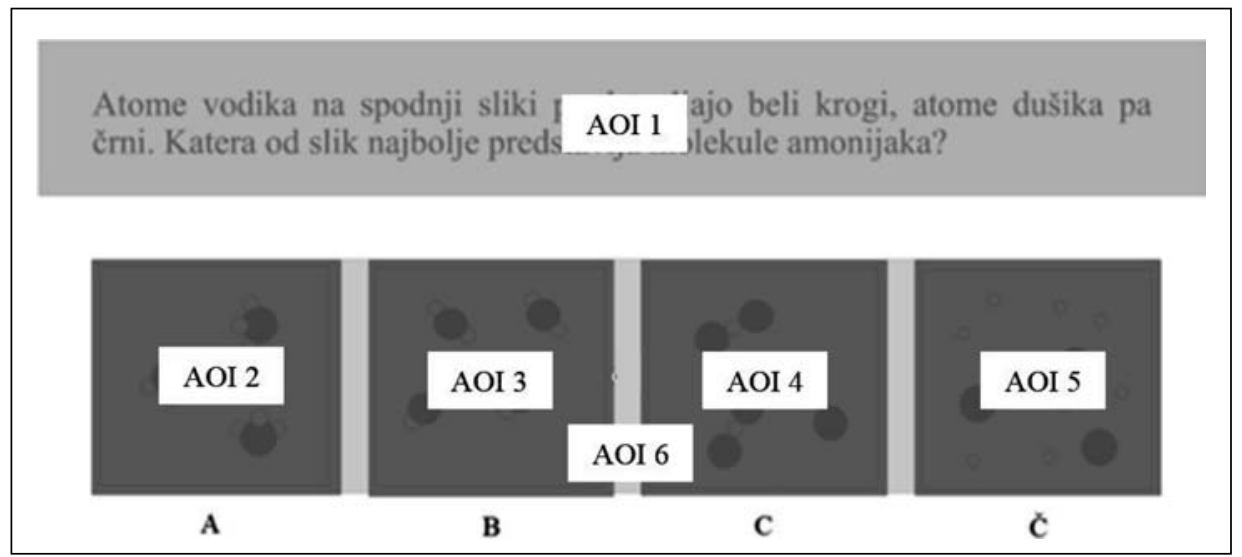

Figure 1. Example of a task divided into AOIs (AOI $1=$ instructions including the textual explanatory key; AOI 3 to AOI $6=$ particles investigated; AOI 2 = whole area of particles presented) 
when the participant held his or her eye for a minimum of $60 \mathrm{~ms}$ at a specific AOI.

Because the data from eye movements were gathered as part of the information processing while solving tasks, the total amount of time spent in a particular AOI was interpreted as a reflection of the relative amount of attention and consequently reliance paid toward each AOI in service of solving the task. ${ }^{40}$

\section{4. Data Collection}

Data collection took place in two parts. In the first part of the study, participants solved the group from the chemistry knowledge test under standard conditions that were the same for all participants. This part took up to 45 minutes. In the second part, which monitored students' cognitive processes by using eye-tracking technology and an interview, students were selected based on their chemistry knowledge test achievements and they participated individually. After calibrating the eye tracker, the participants were introduced to a pre-task to avoid any effect due to difficulty in understanding the type of tasks or process of recording answers and moving to the next task before starting with the main testing. The participants were asked to write down an answer for each task on a piece of paper and then to press the spacebar to advance to the next screen. After that, the participants completed eight tasks for the problem set displayed on the computer screen at their own pace while eye movements were recorded. Each task was presented on the computer screen without a time limit and in random order. After eye-tracking data were collected, the participants were interviewed and asked to compare tasks from the same type with the following question: "If you compare these two tasks, was there any difference in difficulty between them? If there was a difference, please explain possible reasons." The participants' oral responses were transcribed. The collection of eyetracking and interview data took 30 to 55 minutes.

\section{5. Data Analysis}

To explore the role of the explanatory key when solving tasks based on submicroscopic representations, the collected eye-movement data were first analyzed with Tobii Studio Enterprise. Further analysis was conducted using the Statistical Package for the Social Sciences (SPSS), version 21. The nonparametric test Wilcoxon Ranks Test $(Z)$ was used to evaluate significant differences in absolute and relative total fixation duration (TFD) and fixation count (FC) within particular areas of interest (AOIs) toward the colored versus black-and-white (Section 1) or pictorial versus textual (Section 2) explanatory key.

Participants' interview responses were coded using a coding table. The coding table was derived from a qualitative analysis of $25 \%(n=9)$ of the interviews; the reliability of coding was ensured by independent coding by two researchers (the two authors of this article). Subsequently, both evaluations were contrasted at points where differences occurred and, after consideration, the more appropriate one was chosen. Altogether, 98\% reliability was achieved.

\section{Results and Discussion}

\section{1. Section 1: Investigating the Role of a Colored Versus Black-and-White Explanatory Key Accompanying Submicroscopic Representations}

Section 1 studied the role of colored and black-andwhite explanatory keys. Four tasks were completed by

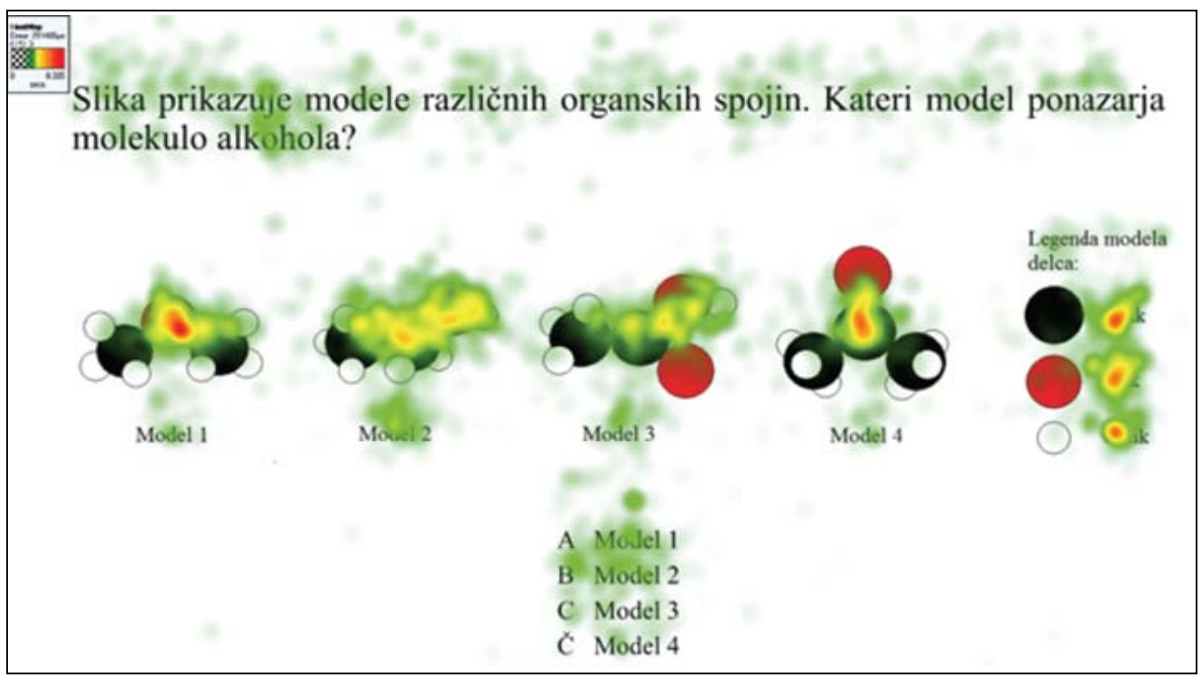

Figure 2. A heat map for Task 1 shows the relative density of fixations using a color gradient. 
each student. Figure 2 shows an example of eye movement using a heat map (Task 1). Red represents a high relative density of fixations and green represents a low relative density of fixations by students participating in the eye-tracking phase of the study. As can be seen, not all models were equally interesting for the students while solving Task 1, and students on average paid more attention to particular areas of the task, as can be recognized from different heat map gradients.

In addition to visualization of eye-fixation data with a heat map, eye tracker provides numerical data for absolute and relative TFD and FC. In Table 2, these data are presented for each task and different areas of interest (the model, key, or whole area of the models presented). Spearman's correlation coefficients $(r=0.834-0.960, p$ $<0.001$ ) indicate that there is a strong correlation between absolute and relative TFD and FC in all tasks in Section 1. The highest relative TFDs and FCs for the explanatory key $(\mathrm{TFD}=48.89 \%$; $\mathrm{FC}=44.15 \%)$ are achieved in the task with a black-and-white representation of the chemical equation (Task 4). The lowest relative TFD$\mathrm{s}$ and FCs for the explanatory key $(\mathrm{TFD}=20.72 \%$; FC $=$ $19.46 \%$ ) are achieved in the task with a black-and-white representation of functional groups of organic compounds (Task 3). However, the differences in relative TFDs and FCs with colored analogues of tasks (Task 2 and Task 1) are small. In order to appreciate how the colored versus black-and-white explanatory key affects students' way of solving tasks, it is important to evaluate the statistical significance of the results, which is presented in Table 3.

The Wilcoxon Ranks Test shows no significant differences in the sum of the absolute mean values of TFD and FC on the AOIs (in particular: Key, Table 3) of the colored versus black-and-white explanatory key from Table 3 (TFD: $Z=-1.154, p=0.248$; FC: $Z=-0.295, p=$ $0.768)$. Students devoted approximately $30 \%$ of task-solving time to explanatory keys (Figure 2), whereby no significant differences in the sum of the relative mean values of TFD and FC on AOIs (in particular: Key, Table 3 ) of the colored versus black-and-white key are noticed (TFD: $Z=$ $-0.915, p=0.360$; FC: $Z=-0.915, p=0.360$ ). The sum of TFD and FC on whole AOIs (in particular: Equation or models and key, Table 3) of colored versus black-andwhite tasks was also not significantly different (TFD: $Z=$ $-1.086, p=0.278$; FC: $Z=-0.902, p=0.367$ ). Based on these results, it can be summarized that the presence of color in the key does not influence the time students spend solving tasks, nor the time that is spent processing the key regardless of its nature.

The results described are also in line with the data gathered from interviews with students (Table 4).

Table 2. Mean values of absolute and relative TFD and FC for tasks 1 to 4.

\begin{tabular}{|c|c|c|c|c|c|c|c|c|}
\hline \multirow{3}{*}{ Task } & \multirow{3}{*}{ Type of key } & \multirow{3}{*}{ Content } & \multirow{3}{*}{$\begin{array}{c}\text { Eye-movement } \\
\text { measures }\end{array}$} & \multicolumn{4}{|c|}{ Area of interest (AOI) } & \multirow{3}{*}{ Key } \\
\hline & & & & Model 1 & Model 2 & Model 3 & Model 4 & \\
\hline & & & & \multicolumn{4}{|c|}{ Whole area of models presented } & \\
\hline \multirow{4}{*}{1} & \multirow{8}{*}{ Colored } & \multirow{4}{*}{$\begin{array}{l}\text { Functional } \\
\text { groups of } \\
\text { organic } \\
\text { compounds }\end{array}$} & TFD [s] & 2.88 & $\begin{array}{r}4.13 \\
12.44\end{array}$ & 3.01 & 2.10 & 3.25 \\
\hline & & & TFD [\%] & & 78.12 & & & 21.88 \\
\hline & & & $\mathrm{FC}[$ count $]$ & 10.06 & $\begin{array}{l}16.41 \\
49.59 \\
\end{array}$ & 13.62 & 8.53 & 13.18 \\
\hline & & & $\mathrm{FC}[\%]$ & & 78.80 & & & 21.20 \\
\hline \multirow{4}{*}{2} & & \multirow{4}{*}{$\begin{array}{l}\text { Chemical } \\
\text { equation }\end{array}$} & TFD [s] & 2.18 & $\begin{array}{l}1.23 \\
7.47 \\
\end{array}$ & 2.25 & 1.18 & 5.76 \\
\hline & & & TFD [\%] & & 56.19 & & & 43.81 \\
\hline & & & $\mathrm{FC}[$ count $]$ & 7.88 & $\begin{array}{r}6.21 \\
33.32\end{array}$ & 9.62 & 5.76 & 25.12 \\
\hline & & & $\mathrm{FC}[\%]$ & & 56.69 & & & 43.31 \\
\hline \multirow{4}{*}{3} & \multirow{8}{*}{$\begin{array}{c}\text { Black- } \\
\text { and-white }\end{array}$} & \multirow{4}{*}{$\begin{array}{l}\text { Functional } \\
\text { groups } \\
\text { of organic } \\
\text { compounds }\end{array}$} & TFD $[\mathrm{s}]$ & 4.42 & $\begin{array}{r}3.42 \\
16.45 \\
\end{array}$ & 5.25 & 3.26 & 3.86 \\
\hline & & & TFD [\%] & & 79.28 & & & 20.72 \\
\hline & & & FC [count] & 16.12 & $\begin{array}{l}14.65 \\
65.85 \\
\end{array}$ & 21.79 & 13.88 & 14.97 \\
\hline & & & $\mathrm{FC} \mathrm{[ \% ]}$ & & 80.54 & & & 19.46 \\
\hline \multirow{4}{*}{4} & & \multirow{4}{*}{$\begin{array}{l}\text { Chemical } \\
\text { equation }\end{array}$} & TFD [s] & 1.25 & 1.85 & $\begin{array}{l}2.40 \\
6.94\end{array}$ & 0.45 & 7.00 \\
\hline & & & TFD [\%] & & & 51.11 & & 48.89 \\
\hline & & & $\mathrm{FC}$ [count] & 5.44 & 8.26 & $\begin{array}{c}9.97 \\
32.06 \\
\end{array}$ & 2.71 & 25.12 \\
\hline & & & $\mathrm{FC} \mathrm{[ \% ]}$ & & & 55.85 & & 44.15 \\
\hline
\end{tabular}

Ferk Savec et al.: Beyond the use of an Explanatory Key Accompanying ... 
Table 3. Sum of the mean values of TFD and FC for tasks that involve colored or black-and-white explanatory keys.

\begin{tabular}{lcrrr}
\hline Type of key & $\begin{array}{c}\text { Eye-movement } \\
\text { measures } \\
\text { SUM }\end{array}$ & Equation or models & $\begin{array}{c}\text { Area of interest (AOI) } \\
\text { Key }\end{array}$ & $\begin{array}{c}\text { Equation or models } \\
\text { and key }\end{array}$ \\
\hline Colored & TFD [s] & 19.91 & 9.01 & 28.92 \\
& FC [count] & 82.91 & 38.29 & 121.31 \\
Black-and-white & TFD [s] & 23.40 & 10.86 & 34.26 \\
& FC [count] & 97.91 & 40.09 & 138.00 \\
\hline
\end{tabular}

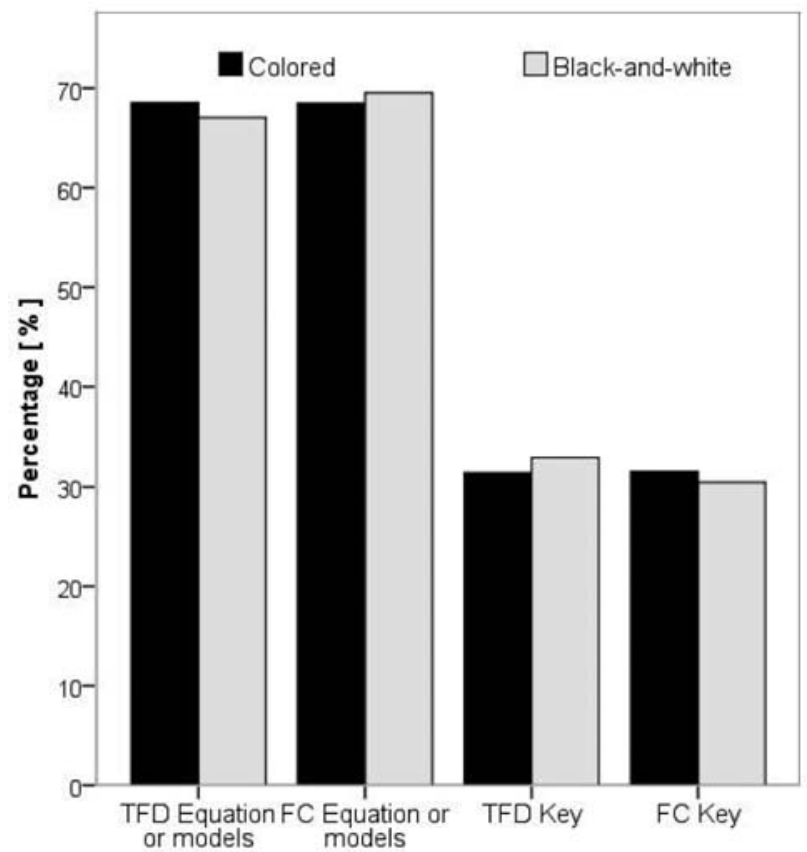

Figure 3. Sum of the relative mean values of TFD and FC on AOI$\mathrm{s}$ of colored versus black-and-white explanatory key

Students stated that the presence of color did not influence their task solving

A typical student comment:

"They're the same; the procedure for solving it is the same."

However, students indicated that color helped them in solving the task with submicroscopic representation, and the rest stated that they had difficulties due to their lack of knowledge.
Typical student comments were:

"Maybe this is easier because of the color because, I don't know, you immediately see that the oxygen is so red, and you see it exactly: oxygen is red. And then it's easier to see. You solve the task faster because if it's gray you're easily confused with black and gray."

"The one with the carboxylic acid was harder because I couldn't remember its functional group."

\section{2. Section 2: Investigating the Role of the Pictorial Versus Textual Explanatory Key Accompanying Submicroscopic Representations}

Section 2 studied the role of pictorial versus textual explanatory keys. Four tasks were completed by each student. Figure 4 shows an example of eye movement using a heat map (Task 8). As explained earlier, red represents a high relative density of fixations and green represents a low relative density of fixations by students.

Figure 4 shows that the AOI of choice A (in particular: Model 1, Table 5) and choice C (in particular: Model 3 , Table 5) have a higher relative density of fixations, which means that students' gaze was more frequently fixed on these representations when solving a particulatelevel task. This is also evident from Table 5, where the mean values of absolute and relative TFD and FC are presented for Tasks 5 through 8 (model, key, or whole area of models presented). Spearman's correlation coefficients $(r$ $=0.777-0.969, p<0.001)$ indicate that there is a strong correlation between absolute and relative TFD and FC in all tasks of Section 2.

Table 5 shows that the highest mean values of relative TFDs and FCs for the explanatory key $(\mathrm{TFD}=69.68 \%$;

Table 4. Analysis of students' opinions about solving tasks in Section 1

\begin{tabular}{|c|c|c|c|c|}
\hline \multirow{2}{*}{$\frac{\text { Task description }}{\text { Taxonomy level }}$} & & & \multicolumn{2}{|c|}{ Students' comparison of task difficulty } \\
\hline & Content & Same difficulty $\left[\%,\left(\mathrm{~N} / \mathrm{N}_{\mathrm{T}}\right)\right]$ & \multicolumn{2}{|c|}{ Different difficulty $\left[\%,\left(\mathrm{~N} / \mathrm{N}_{\mathrm{T}}\right)\right]$} \\
\hline & & & $\begin{array}{c}\text { Color is helpful } \\
{\left[\%,\left(\mathrm{~N} / \mathrm{N}_{\mathrm{T}}\right)\right]}\end{array}$ & $\begin{array}{l}\text { Difficulties due to lack of } \\
\text { knowledge }\left[\%,\left(\mathrm{~N} / \mathrm{N}_{\mathrm{T}}\right)\right]\end{array}$ \\
\hline \multirow{2}{*}{ Application } & \multirow{2}{*}{ Chemical equation } & \multirow{2}{*}{$57.14(20 / 35)$} & \multicolumn{2}{|c|}{$42.86(15 / 35)$} \\
\hline & & & $37.14(13 / 35)$ & $5.72(2 / 35)$ \\
\hline \multirow{2}{*}{ Application } & Functional groups & \multirow{2}{*}{$65.71(23 / 35)$} & \multicolumn{2}{|c|}{$34.29(12 / 35)$} \\
\hline & of organic compounds & & $14.29(5 / 35)$ & $20.00(7 / 35)$ \\
\hline
\end{tabular}




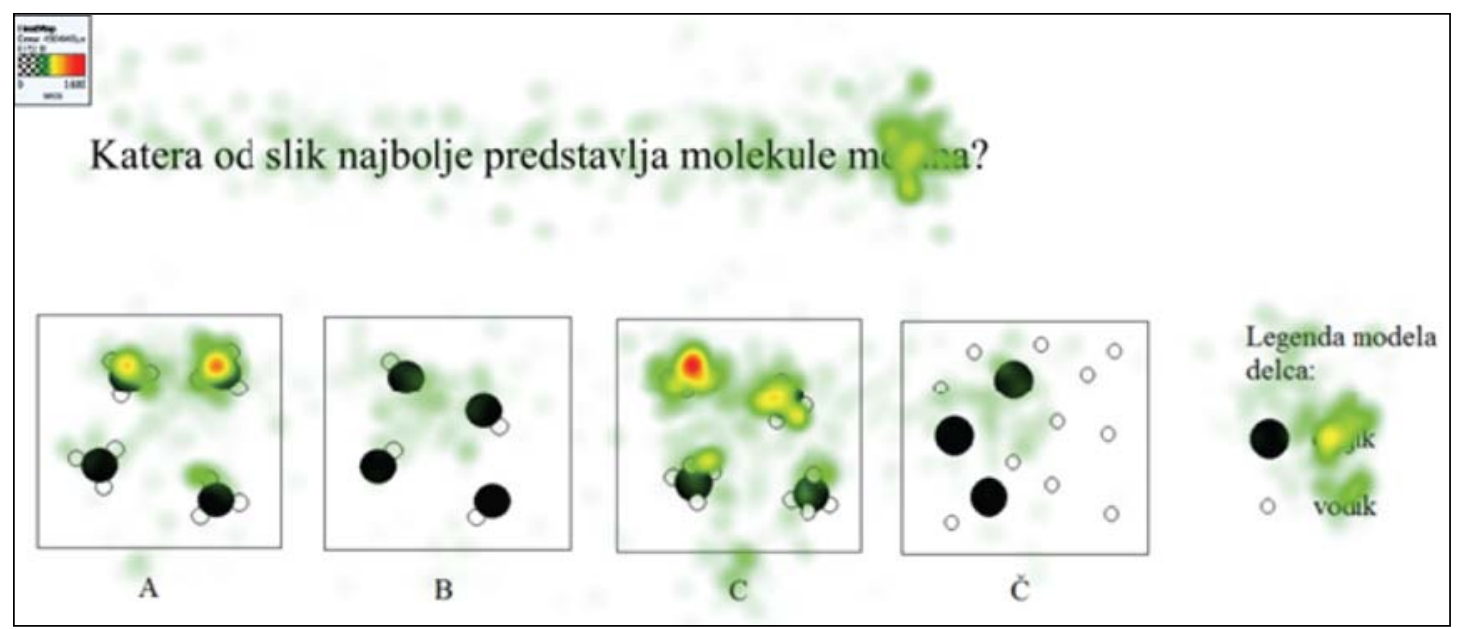

Figure 4. A heat map for Task 8 shows the relative density of fixations using a color gradient.

$\mathrm{FC}=69.09 \%)$ are achieved in the task with a textual key (Task 5), and the lowest mean values of relative TFDs and FCs $(\mathrm{TFD}=42.30 \%$; FC $=44.48 \%$ ) are achieved in the task with a pictorial representation (Task 8). To examine how the textual versus pictorial explanatory key is involved in students' way of solving tasks, the Wilcoxon Ranks Test was used (Table 6).
The results presented in Table 6 show how a pictorial versus textual explanatory key affects students' way of solving tasks based on submicroscopic representations. The AOI for the pictorial explanatory key also includes task instruction in order to equalize the AOI with the textual explanatory key when the task instructions and key

Table 5. Mean values of absolute and relative TFD and FC for tasks 5 to 8 .

\begin{tabular}{|c|c|c|c|c|c|c|c|c|}
\hline \multirow[b]{2}{*}{ Task } & \multirow[b]{2}{*}{$\begin{array}{c}\text { Type of } \\
\text { key }\end{array}$} & \multirow[b]{2}{*}{ Content } & \multirow{2}{*}{$\begin{array}{c}\text { Eye- } \\
\text { movement } \\
\text { measures }\end{array}$} & \multicolumn{4}{|c|}{ Area of interest (AOI) } & \multirow[b]{2}{*}{ Key } \\
\hline & & & & Model 1 & \multicolumn{3}{|c|}{ Whole area of models presented } & \\
\hline \multirow{4}{*}{5} & \multirow{8}{*}{ Textual } & \multirow{8}{*}{$\begin{array}{l}\text { Simple } \\
\text { common } \\
\text { compounds }\end{array}$} & TFD [s] & 0.55 & 0.63 & 1.48 & 0.60 & 7.27 \\
\hline & & & TFD [\%] & \multicolumn{4}{|c|}{30.32} & 69.68 \\
\hline & & & FC [count] & 2.68 & 3.79 & $\begin{array}{r}7.09 \\
16.44 \\
\end{array}$ & 2.68 & 37.97 \\
\hline & & & FC [\%] & & & 30.91 & & 69.09 \\
\hline \multirow{4}{*}{6} & & & TFD [s] & 2.05 & 0.86 & $9 \quad 0.80$ & 0.52 & 7.91 \\
\hline & & & TFD [\%] & \multicolumn{4}{|c|}{33.76} & 66.24 \\
\hline & & & FC [count] & 7.15 & $\begin{array}{l}4.29 \\
\quad 1\end{array}$ & $4^{3.85}$ & 2.41 & 41.26 \\
\hline & & & FC [\%] & \multicolumn{4}{|c|}{30.41} & 69.59 \\
\hline \multirow{4}{*}{7} & \multirow{8}{*}{ Pictorial } & \multirow{8}{*}{$\begin{array}{l}\text { Simple } \\
\text { common } \\
\text { compounds }\end{array}$} & TFD [s] & 0.78 & 0.86 & $\begin{array}{l}1.47 \\
8\end{array}$ & 2.02 & 6.39 \\
\hline & & & TFD [\%] & & & & & 55.28 \\
\hline & & & FC [count] & 3.24 & 3.94 & 5.91 & 8.15 & 30.26 \\
\hline & & & FC [\%] & & & & & 57.60 \\
\hline \multirow{4}{*}{8} & & & TFD [s] & 1.90 & 0.80 & $\begin{array}{r}3.07 \\
4\end{array}$ & 0.59 & 4.26 \\
\hline & & & TFD [\%] & \multicolumn{4}{|c|}{57.70} & 42.30 \\
\hline & & & FC [count] & 6.85 & 4.35 & $6^{11.56}$ & 3.15 & 19.91 \\
\hline & & & FC [\%] & \multicolumn{4}{|c|}{55.52} & 44.48 \\
\hline
\end{tabular}


are jointly presented (AOI Instructions and key). The sum of the absolute mean values of TFD on AOIs (in particular: Models, instructions, and key, Table 6) of the pictorial versus textual explanatory key is not significantly different (TFD: $Z=-0.445, p=0.657$ ), however, the number of FC is significantly different $(\mathrm{Z}=-2.360, p=0.018)$ due to difference in number of fixations on models. This means that they used the same amount of time for solving tasks with a pictorial or the textual explanatory key, but made more fixations when solving tasks with textual explanatory key. It is important to note that the Wilcoxon Ranks Test shows significant differences in the sum of the relative mean values of TFD and FC on AOIs (in particular: Instructions and key, Table 6) of the pictorial and textual explanatory key (TFD: $Z=-3.838, p<0.001$; FC: $Z=$ $-4.626, p<0.001)$. Significant differences in the sum of the mean values of TFD as well as the sum of the mean values of FC also indicate that students not only spent more time but also fixated on the explanatory key more often while solving the task in the case of a textual key in comparison to a pictorial key. As a reflection of attention, this indicates that while solving the task students pay greater attention to the AOI of the textual key. ${ }^{25}$

This can also be seen in Figure 5, where students devoted approximately $70 \%$ of task-solving time to textual explanatory keys, but only approximately $50 \%$ of tasksolving time was used in the case of a pictorial key. The difference described is statistically significant (TFD: $Z=$ $-4.967, p<0.001$; FC: $Z=-5.052, p<0.001$; Figure 5).

It is interesting that in their interviews the students revealed that they did not detect the differences in the textual versus pictorial explanatory keys as relevant for solving tasks (Table 7).

In particular, $91.43 \%$ of students explained that the type of key presentation in terms of textual versus pictorial does not contribute to a different way of solving the task; some of them $(f=8.57 \%)$ attributed their difficulties

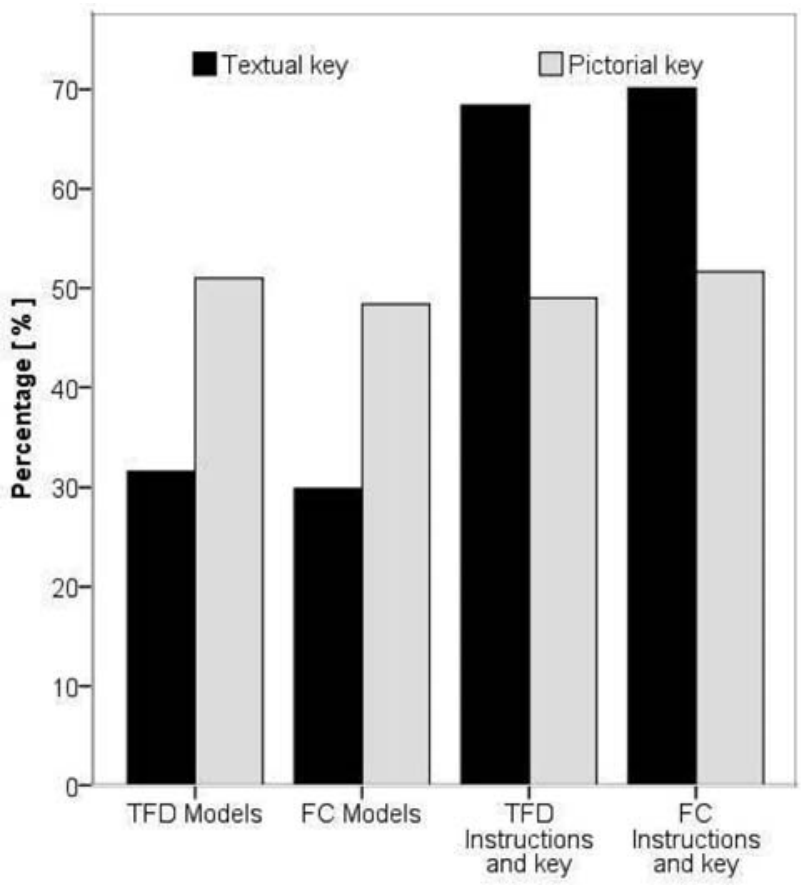

Figure 5. Sum of the relative mean values of TFD and FC on AOI$\mathrm{s}$ of pictorial or text explanatory keys

in solving tasks to their lack of chemistry knowledge.

Typical student comments:

"There are no differences; if you know the molecular formula, they're all easy."

"The one with the methane was the hardest. I didn't know if it was $\mathrm{CH}_{3}$ or $\mathrm{CH}_{4}$."

\section{Conclusions}

When learning chemistry, learners are often challenged by various representations at the submicroscopic level

Table 6. Sum of the mean values of TFD and FC of tasks that involve pictorial or text explanatory keys.

\begin{tabular}{|c|c|c|c|c|}
\hline Type of key & $\begin{array}{l}\text { Eye-movement } \\
\text { measures SUM }\end{array}$ & Models & $\begin{array}{l}\text { Area of interest (AOI) } \\
\text { Instructions and key }\end{array}$ & Models, instructions, and key \\
\hline \multirow[t]{2}{*}{ Textual } & TFD [s] & 7.40 & 15.17 & 22.58 \\
\hline & FC [count] & 34.38 & 79.24 & 113.618 \\
\hline \multirow[t]{2}{*}{ Pictorial } & TFD [s] & 11.72 & 10.65 & 22.37 \\
\hline & FC [count] & 47.85 & 50.21 & 98.029 \\
\hline
\end{tabular}

Table 7. Analysis of students' opinion about solving tasks in Section 2

\begin{tabular}{|c|c|c|c|c|}
\hline \multicolumn{2}{|c|}{ Task description } & \multicolumn{3}{|c|}{ Students' comparison of task difficulty } \\
\hline Taxonomy level & Content & Same difficulty $\left[\%,\left(\mathrm{~N} / \mathrm{N}_{\mathrm{T}}\right)\right]$ & Different diff & iculty $\left[\%,\left(\mathrm{~N} / \mathrm{N}_{\mathrm{T}}\right)\right]$ \\
\hline & & & $\begin{array}{c}\text { Pictorial legend is helpful } \\
{\left[\%,\left(\mathrm{~N} / \mathrm{N}_{\mathrm{T}}\right)\right]}\end{array}$ & $\begin{array}{c}\text { Difficulties due to lack } \\
\text { of knowledge }\left[\%,\left(\mathrm{~N} / \mathrm{N}_{\mathrm{T}}\right)\right]\end{array}$ \\
\hline Application & Simple common & $91.43(32 / 35)$ & $000(0 / 35)$ & $857(3 / 35)$ \\
\hline
\end{tabular}


that are included in learning materials to develop students' understanding about scientific concepts and processes at a particulate level.

This study examined students' use of an explanatory key while solving tasks based on submicroscopic representations. With regard to the first research question-whether a colored versus black-and-white pictorial explanatory key affects students' way of solving chemistry tasks based on submicroscopic representations-it can be concluded that the presence of color in the key does not influence the time students spend solving the task nor the time that students spend processing the differently colored pictorial keys. With regard to the second research question-how a pictorial black-and-white versus textual explanatory key affects students' way of solving chemistry tasks based on submicroscopic representations-it was found that students used the same amount of time for solving tasks with a pictorial or textual explanatory key. However, the results indicate that students spent statistically significantly more time processing the textual explanatory key, and also fixated on the explanatory key more often while solving tasks in comparison to the pictorial blackand-white key.

Based on the results, it can be concluded that an explanatory key might play an important role in students' ability to correctly perceive submicroscopic representations while solving tasks or problems comprising submicrorepresentations. Therefore, it would be beneficial for learners for each of the submicroscopic representations in learning materials to be accompanied by an explanatory key, which then enables the reader to accurately recognize the features.

Follow-up studies on the role of explanatory keys and accompanying submicroscopic representations in students' development and use of representational competence are necessary.

\section{Acknowledgements}

This work was supported by the University of Ljubljana's Faculty of Education, project framework " 2015/16" (Internal call for funding research and art projects), project title "Pojasnjevanje uspešnosti reševanja kemijskih nalog na submikro ravni ter preučevanje kompetentnosti bodočih učiteljev kemije za njihovo poučevanje" (Explaining success in solving chemistry tasks at the submicroscopic level, and investigating prospective chemistry teachers' skills for teaching these).

\section{References}

1. S. R. Hinze, D. N. Rapp, V. M. Williamson, M. J. Shultz, G. Deslongchamps, K. C. Williamson, Learn. Instr. 2013, 26, $12-21$. http://dx.doi.org/10.1016/j.learninstruc.2012.12.002

2. B. Šket, B., S. A., Glažar, J. Vogrinc, Acta Chim. Slov. 2015, $62,462-472$. http://dx.doi.org/10.17344/acsi.2014.1148

3. G. Nicoll, Int. J. Sci. Educ. 2001, 23, 707-730. http://dx.doi.org/10.1080/09500690010025012

4. M. L. Chiu, M. H. Chiu, C. Y. Ho, Proceedings of the National Science Council, 2002, 12, 91-99.

5. E. Adadan, F. Savasci. Int. J. Sci. Educ. 2002, 34, 513-544. http://dx.doi.org/10.1080/09500693.2011.636084

6. K. deBerg, Chem. Educ. Res. Pract. 2012, 13, 8-16. http://dx.doi.org/10.1039/C1RP90056K

7. I. Devetak, J. Vogrinc, S. A. Glažar. Res. Sci. Educ. 2009, 39, 157-179. http://dx.doi.org/10.1007/s11165-007-9077-2

8. B. Davidowitz, G. Chittleborough, E. Murray, Chem. Educ. Res. Pract. 2010, 11, 154-164. http://dx.doi.org/10.1039/C005464J

9. I. Devetak, E. Drofenik Lorber, M. Juriševič, S. A. Glažar, Chem. Educ. Res. Pract. 2009, 10, 281-290. http://dx.doi.org/10.1039/B920833J

10. J. K. Gilbert, in: J. K. Gilbert (Ed.): Visualization in Science Education, Springer, Dordrecht, 2005, pp. 9-27. http://dx.doi.org/10.1007/1-4020-3613-2_2

11. J. K. Gilbert, M. Reiner, M. Nakhleh. Visualization: Theory and practice in science education. Springer, New York, 2008, 325 pp. http://dx.doi.org/10.1007/978-1-4020-5267-5

12. A. H. Johnstone, Sch. Sci. Rev. 1982, 64, 377-379.

13. A. H. Johnstone, J. Comput. Assist. Learn. 1991, 7, 75-83. http://dx.doi.org/10.1111/j.1365-2729.1991.tb00230.x

14. I. Eilks, in: V. G. Tsaparlis, H. Sevian (Eds.): Concepts of Matter in Science Education, Springer, New York, 2013, pp. 213-230. http://dx.doi.org/10.1007/978-94-007-5914-5_10

15. H. D. Barke, H. Wirbs, Chem. Educ.: Res. Pract. Eur. 2002, 3, 185-200.

16. V. Ferk Savec, I. Sajovic, K. S. Wissiak Grm, in: J. K. Gilbert (Ed.): Multiple Representations in Chemical Education, Springer, Berlin, 2009, pp. 309-331. http://dx.doi.org/10.1007/978-1-4020-8872-8_14

17. V. Ferk Savec, M. Vrtačnik, J. K. Gilbert, C. Peklaj, Acta Chim. Slov. 2006, 53, 381-390.

18. L. T. Tien, M. A. Teichert, D. Rickey, D. J. Chem. Educ. 2007, 84, 175-180. http://dx.doi.org/10.1021/ed084p175

19. R. M. Kelly, L. L. Jones, J. Chem. Educ. 2008, 85, 303-309. http://dx.doi.org/10.1021/ed085p303

20. S. M. Al-Balushi, S. H. Al-Hajri, Chem. Educ. Res. Pract. 2014, 15, 47-58. http://dx.doi.org/10.1039/C3RP00074E

21. J. H. Mathewson, Sci. Educ. 1999, 83, 33-54. http://dx.doi.org/10.1002/(SICI)1098-237X(199901) 83:1<33: :AID-SCE2>3.0.CO;2-Z

22. K. J. Schönborn, T. R. Anderson, Biochem. Mol. Biol. Educ. 2006, 34, 94-102. http://dx.doi.org/10.1002/bmb.2006.49403402094

23. P. B. Griffard, in: D. F. Treagust, C. Y. Tsui (Eds.): Multiple Representations in Biological Education, Springer, Dor- 
drecht, 2013, pp. 164-184.

24. B. Tversky, M. Agrawala, J. Heiser, P. U. Lee, P. Hanrahan, D. Phan, C. Stolte, M. P. Daniele, in: L. Magnani (Ed.): Model-Based Reasoning in Science and Engineering, King's College, London, 2007, pp. 1-20.

25. S. R. Hinze, V. M. Willamson, M. J. Shultz, K. C. Willamson, G. Deslongchamps, D. N. Rapp, Cogn. Process. 2013, 14, 129-142. http://dx.doi.org/10.1007/s10339-013-0539-3

26. A. T. Stull, M. Gainer, S. Padalkar, M. Hegarty, J. Chem. Educ. 2016, 93, 994-1001. http://dx.doi.org/10.1021/acs.jchemed.6b00194

27. M. Stieff, S. Scopelitis, M. E. Lira, D. Desutter, Sci. Educ. 2016, 100, 344-363. http://dx.doi.org/10.1002/sce.21203

28. V. Ferk, M. Vrtacnik, A. Blejec, A. Gril, Int. J. Sci. Educ. 2003, 25, 1227-1245. http://dx.doi.org/10.1080/0950069022000038231

29. R. Kozma, J. Russell, in: J. Gilbert (Ed.): Visualization in Science Education, Kluwer, London, 2005, pp. 121-146. http://dx.doi.org/10.1007/1-4020-3613-2_8

30. V. Ferk Savec, M. Vrtačnik, J. K. Gilbert, in: J. Gilbert (Ed.): Visualization in Science Education, Springer, Dordrecht, 2005, pp. 269-300. http://dx.doi.org/10.1007/1-4020-3613-2_14

31. A. T. Stull, M. Hegarty, B. L. Dixon, M. Stieff, Cogn. Instr. 2012, 30, 404-434. http://dx.doi.org/10.1080/07370008.2012.719956

32. D. N. Rapp, C. A. Kurby, in: J. Gilbert, M. Reiner, M. Nakh- leh (Eds.): Visualization: Theory and Practice in Science Education, Springer, Dordrecht, 2008, pp. 29-52. http://dx.doi.org/10.1007/978-1-4020-5267-5_2

33. D. Crow, Visible signs, AVA, Lausanne, Switzerland, 2003, $192 \mathrm{pp}$.

34. H. Dreyfuss, Symbol Sourcebook: An Authoritative Guide to International Graphic Symbols. Van Nostrand Reinhold, New York, 1984, 288 pp.

35. B. Fantini, Hist. Philos. Life Sci. 2006, 28, 567-593.

36. P. B. Griffard, in: D. F. Treagust, C.Y. Tsui (Eds.), Multiple Representations in Biological Education, Springer, Dordrecht, 2013, pp. 164-184.

37. J. Perkins, J. Nat. Sci. Ill. 2011, 43, 15-20.

38. N. Campbell, J. Reece, L. Urry, M. Cain, S. Wasserman, P. Minorsky, R. B. Jackson, Biology (8th ed.), Pearson, San Francisco, 2008, 1267 pp.

39. P. Atkins, T. Overton, J. Rourke, M. Weller, F. Armstrong. Inorganic Chemistry (4th ed.), Oxford University Press, New York, 2006, 822 pp.

40. S. R. Hinze, D. N. Rapp, V. M. Williamson, M. J. Shultz, G. Deslongchamps, K. C. Williamson, Learn. Instr. 2013, 26, 12-21.

http://dx.doi.org/10.1016/j.learninstruc.2012.12.002

41. M. Stieff, M. Hegarty, G. Deslongchamps, Cogn. Instr. 2011, 29, 123-145.

42. K. Rayner, Q. J. Exp. Psychol. 2009, 62, 1457-1506.

43. K. Rayner, Psychol. Bull. 1998, 124, 372-422.

\section{Povzetek}

Pri učenju kemije se učenci, dijaki in študenti srečujejo z različnimi vizualizacijskimi gradniki, ki ponazarjajo delčno raven naravoslovnih pojmov in procesov. Pri tem se pogosto privzame, da so ti vizualizacijski gradniki učečim v podporo pri razumevanju in da so jih sposobni učinkovito uporabiti pri reševanju nalog in problemov. Name raziskave je bil preučiti uporabo legende med reševanjem nalog, ki temeljijo na submikroskopskih reprezentacijah. Preučevane so bile naslednje lastnosti legende: (1) barvna napram črno-bela, in (2) slikovna napram besedilna. Vzorci očesnih fiksacij in ustne razlage študentov so pokazali, da uporaba barvne legende v primerjavi s črno-belo ne vpliva na število in čas fiksacij pogleda študentov na legendo med reševanjem nalog. Ugotovljene pa so bile pomembne razlike povezane $\mathrm{z}$ uporabo slikovne napram besedilni legendi; tako študenti namenijo več časa in pogosteje fiksirajo pogled na besedilno legendo v primerjavi s slikovno. Rezultati kažejo, da ima lahko način vključitve in vrsta uporabljene legende pomembno vlogo pri razvijanju razumevanja reprezentacijske kompetence učečih v zvezi z submikroskopskimi reprezentacijami. 